\title{
Secession Right - an Anti-Federal Principle? Comparative Study of Federal States and the EU
}

\author{
Florentina Harbo \\ Norwegian Institute for Strategic Studies \\ Youngstorget 5, N-0181, Oslo, Norge (Norway) \\ Tel: 47-22-396-074Ｅ-mail: florentina.harbo@noriss.no
}

\begin{abstract}
This article argues that the secession right is incompatible with federalism. The right of secession is one of the main criteria to differentiate a federal state from a confederation and a Bund. There are only a few federal states that recognised the secession right in their constitutions and they failed. On the other hand, there are even confederations which did not accept a secession right in their treaties. The issue of secession has always been very controversial in the European Union, which is a Bund (federal polity), but its Treaties never included it. The radical change is the introduction of Art. I-60 in the Treaty Establishing a Constitution for Europe ("Reform Treaty" now), which might give a new face to the EU if ever it is ratified.
\end{abstract}

Keywords: Secession, Federalism, Federal state, EU

\section{Introduction}

Modern politics started with an act of secession, in the form of the American Declaration of Independence. The issue of secession is very significant in the framework of federal states or unions. The secession right, the location of sovereignty, the founding pact or the legal document and citizenship are the main criteria used to differentiate a confederation from a federal state and a federal polity or Bund. (Note 1) In a confederation, the individual member states sign an international treaty, but keep their sovereignty. The confederation is characterised by multiple demoi and individual citizenships. Its member states are allowed to withdraw, just as is the case in an international organisation, but not unilaterally. In a federal state, sovereignty is divided or shared between the different levels of government as defined by the federal constitution. Individual member states are thus transformed in federal entities, the federal state creating one demos and one common citizenship. All off these elements exclude the secession right for the entities. Because it allows for secession, the confederation is less a stable political order, while the federal state retains the solidity of a state (Beaud 1999). The classical state theory of the $19^{\text {th }}$ century divided the possible federal structures into federations, confederations, and tertium non datur. By contrast, the theory of the Bund abandons the federation-confederation dichotomy and can also be useful for the EU, as Schönberger (2004) suggests. The definition of the Bund includes all those federal structures that are based on voluntary associations of states and are more than confederations, but do not yet constitute federations. A Bund is a political territorial or functional union of political entities that have a common goal. Social and political relations exist among the entities of the Bund. A significant feature of the Bund is the principle of the federal loyalty (Bundestreue) as a reciprocal legal duty. In a Bund sovereignty is divided on the basis of its founding compact, but remains open and is unfinished (Schmitt 1928/1957). The Bund is composed of multiple demoi and the citizens have double citizenship. Crucially, the founding compact does not provide any explicit secession right.

The aim of this article is to analyse the secession right in theory and practice and to show why it is incompatible with federalism. The analysis will be based on a comparative study of federal states and the EU.

The first part of this article will define the various concepts and argue why the secession right is incompatible with federalism. The second part will analyse particular experiences of secession in federal states. The final part will focus on the secession right with regard to the EU.

\section{Why is the secession right incompatible with federalism?}

A variety of terms are used by scholars in the discussion of theories of secession. The terms generally differ according to the fields in which individual scholars operate: lawyers of international law, political scientists, philosophers, historians, geographers and finally scholars of federalism. All use interchangeable notions such as secession, (unilateral) withdrawal, exit clause or option, as well as self-determination. This analysis will not deal with the right of secession as a subject of international law, when a group secedes from a unitary state and seeks international recognition - the right 
of self-determination. (Note 2) It will rather discuss the secession right in federal states. Thus, the term "self-determination" will not be used in this article. The notions of secession and withdrawal will be used interchangeably. The term "secession" comes from the Latin word secedere and means: "The fact of an area or group becoming independent from the country or larger group that it belongs to". (Note 3) Buchanan defines secession as: "a form of refusal to acknowledge the state's claim to political authority" (Buchanan 1991, 4). A political entity secedes from a union when it no longer agrees with its policy - only, however, only when this right is clearly introduced in the legal document of the union. For the purpose of this analysis, I define secession as an act of formal withdrawal from membership in a federal polity, whereby a group of people and its territory breaks all the ties (e.g. political, economic, cultural etc.) it had with the federal polity.

Political theorists have traditionally worked with notions such as constitution and dissolution of polities, but they have until recently neglected the issue of secession. Certain philosophers treated this issue in a partial manner: Althusius, for example, mentions secession in his analysis of the justified remedies against tyranny (1603/1965, chapter XXXVIII). Grotius emphasised that in exceptional cases a part of a state may have the right to secede. Pufendorf, on the other hand, basing his arguments on the Hobbesian theory of absolute sovereignty of the ruler, maintains that secession is not permissible (in: Beran 1984, 22). Classical social-contract theory was dealing with the creation of political communities by voluntary mutual agreements, where the consent of the people was the basis of the authority of government. The liberal theory of John Locke bases the individual right to emigration and the collective right to revolution on this principle, but is opposed to secession (Locke 1689/2002). The American revolutionaries extended the Lockean right of resistance to tyranny in order to justify the right of secession (Buchheit 1978, 55). In the framework of federal states, John C. Calhoun was the first who tried to justify the right of secession in his "States Rights" (1851) doctrine. Before his claims, the only alternative to the functioning of the institutions in a federal union had been the act of revolution. Calhoun argued that if a federal unity's existence is threatened and constitutional principles are not respected, then this unity has the right to secede. If a revision of the constitution does not succeed, a state may secede: "That a State, as a party to the constitutional compact, has the right to secede, - acting in the same capacity in which it ratified the constitution, - cannot, with any show of reason, be denied by any one who regards the constitution as a compact" (Calhoun (1851) in: Cralle 2003: 179). In order to protect the Northern American South from political attack, Calhoun proposed the theory of state sovereignty within the federal union and derived from it the doctrines of nullification and secession. The right of secession from the union followed directly from state sovereignty. For Calhoun, the Constitution was a treaty concluded among sovereign states: thus, the interpretation of the text according to the law of the treaties belongs to each of the parts. Significantly, however, Madison had earlier mentioned that there could be no other form of secession than revolution, as secession could not take place without revolution (in: Hamilton et al. 1787-1788/1982).

Most of the scholars on federalism argue that federalism and the secession right do not go hand in hand: once the secession right is established one cannot talk any longer of a federal constitution. A federal unit does not have the right to exit from the union that it has in a confederation (though not in this case unilaterally). As Jellinek emphasises: „Sezession der Staaten aus der Union ist daher nicht der Gebrauch eines natürlichen Rechtes sondern Hochverrat" (Jellinek 1882/1969, 255). (Note 4) A federal polity is created to last and duration excludes secession (Steiger 1966, 151). Others argue that secession may become a justified right. Harry Beran develops a liberal normative theory of secession and claims that liberalism requires that secession be permitted if it is effectively desired by a territorially concentrated group and is morally and practically possible. This is required by the value liberalism places on freedom, by a liberal theory of popular sovereignty, and by a presupposition of legitimate majority rule. The permissive principle of secession in this case is neither theoretically, nor practically unacceptable (Beran 1984, 21-31). Even though the federal units have the right of expression in liberal democracies, this is not enough as the only way they could express their particularity would be to secede. However, such notions as effectiveness, morality and practicability are difficult to measure. In addition to this, there emerges the further problem of where the limits to this should be drawn? Michael Walzer underlines: "Separation, secession, partition, liberation - all for the sake of statehood - point the way toward a kind of international settlement ... That the process is uneven, that it is violent, that it produces anomalies along the way (states without nations, nations with more than one state): none of these is a reason for backing away from it" (Walzer 1986, 230-231). He also supports the idea that secession might be a justified right. However, the price to pay is very high. John Rawls wrote in The Law of Peoples about the right to self-determination: “... the right to independence, and equally the right to self-determination, hold only within certain limits, yet to be specified by the Law of Peoples for the general case" (Rawls 1999, 38). However, Rawls did not develop a theory of secession since he described the law of peoples in which all peoples had their own state. (Note 5) Michel Seymour underlines that states have a general primary right to self-determination and, what is new, a primary right to internal self-determination for their constitutive nations. The latter have the right to secede only if they suffer important injustices, but the injustices should not be limited to the violation of human rights and annexation of territories. The moral importance of individuals and peoples should be taken into account. (Note 6) Seymour thus concludes that secession could be compatible with federalism. John Stuart Mill was the one who paid much attention to the moral and 
philosophical justifications for secession as well (Barktus 1999, 15-16).

Now I will examine the main reasons, which explain why the secession right is not federal (Note 7):

(1) If secession is legally recognised in a federal polity, it could weaken the federal system by giving a tool of political coercion to the federal units, i.e. greater bargaining power. Thus, every time they do not agree with the policy of the federal level, they will threaten it with secession. The threat might be particularly dangerous if the federal unit can or might want to exist on its own.

(2) The secession right could have negative consequences on fundamental federal principles such as cooperation and solidarity. When a federal unit wants to secede, it no longer accepts its federal obligations. This could lead to the fact that the other federal units losing their trust in the federal polity and thus to a breakdown in "federal loyalty" (Bundestreue) among the entities.

(3) If the constitution provides a right to secede, each federal unit will be vulnerable to threats of secession coming from other units.

(4) A possibility of secession could be an element of uncertainty for federal economic development and unity of the system as a whole.

(5) A federal polity that admits the right of secession demonstrates that it is generally failing (e.g. former USSR and Yugoslavia).

The secession right may create problems in every form of constitution, and not only in federal constitutions. Even if secession might be justified as a matter of politics or morality (Note 8), not including it in a constitution could prevent many problems (Sunstein 1991, 635). This is for the following reasons:

- The secession right would increase the risks of ethnic and factional struggle;

- Reduce the prospects for compromise and deliberation in government;

- Raise dramatically the stakes of day-to-day political decisions and introduce irrelevant and illegitimate considerations into those decisions;

- Create dangers of blackmail, strategic behaviour and exploitation;

- Endanger the prospects for long-term self-governance.

Having seen the arguments in favour of the thesis that secession is incompatible with federalism and the reasons why secession should not be included in any constitution, not only in a federal one, the conclusion can be drawn that secession is not only constitutionally, politically, economically or geographically a problem of democracy: it is also immoral and inconsistent with the very idea of democracy.

Exiting a federal state means for a member to break the pact, but does not automatically mean revolting against a power. Not respecting a contract can sometimes be legally justified, but acting against a constitutional power can never be justified. There is no contractual clause that could justify the ultra posse nemo obligator. It is possible to exit a confederation, since it is based on the autonomous decision of states, but a union of public law can never be dissolved in a legal way by the member states. "Political suicide" is not a juridical category (Bismarck quoted in: Jellinek 1900/1929). In a confederation, the states do not give up all their sovereignty, but this is no longer the case in a federal state. Carl Schmitt criticises the right of secession when he talks about a Bund:

Entweder Dauer des Bundes, d. h. weder Sezession noch Nullifikation; oder selbständige politische Existenz der Mitgliedstaaten, d.h. - wenn auch nur im äußersten Falle - Nullifikation und Sezession. Aber der Begriff einer aus Staaten zusammengesetzten, dauernden und doch ihre vertragliche Grundlage nicht verlassenden politischen Einheit erscheint als etwas im höchsten Grade Widerspruchsvolles (Schmitt 1928/1957, 375) (Note 9).

Schmitt also bases his arguments on duration. Before a sovereign state enters a federal polity at all, it has to abandon the secession right. Preuss does not even question the fact that the secession right and the federal state exclude each other (Note 10): „The renunciation of secession precedes federalism, not vice versa“ (Preuss 1997, 24). If a federal unit leaves the federal state, it dissolves the constitution and endangers the other units. These are convincing reasons to avoid including the secession right in a federal constitution. All these arguments have shown that the secession right is theoretically incompatible with federalism.

A federal constitution may prevent secession by: a) a very clear vertical and horizontal division of powers, b) checks and balances, so that the federal units do not feel oppressed by the federal level and vice versa that the federal level does not feel threatened by the demands of the federal units and c) a system of judicial review. In order to avoid secession the federal state could propose such options as decentralisation, devolution or other forms of self-government. All these constitutional measures may contribute to the survival of federalism. Guy Laforest introduces the idea of "partnership loyalty" in this context. Patience, calmness and dialogue are required in order to build a partnership. Everything 
depends on the reciprocity of concessions and on the clear-mindedness of the parties seeking a balance: “ ... a balance that will remain ever precarious" (Laforest 1998, 78-79). This is also a means of avoiding secession.

Wheare (1946/1963, 90-92) doubts whether the right of secession is incompatible with federalism as a matter of logic. He makes the distinction between the right of secession and the right to nullify the laws of the general government. An essential requirement of a federal government is that there should be no right of secession from the federal state on the part of the regional governments. If such an action is permitted, it means that the general government is subordinated to the regional governments or vice versa thus implying the end of the federal union. As such, what is really inconsistent is the right to nullify the laws of the general government. An example here could be the case of the Southern States of the US, which pleaded for the nullification of the laws of Congress in the event if such laws proved to be unsatisfactory. Calhoun (1851 in: Cralle 200) asserted that the general government was the agent of the states and that the states were therefore entitled to nullify any acts of their agent meeting their disagreement. Wheare (1946/1963, 92) states that this doctrine of nullification is contrary to federalism, since it places the general government, as a matter of law, in a subordinate position to the regional governments. The federal units continue to be members of the union and at the same time can decide which of the laws of the general government they want to accept. This poses a clear problem. The use of the right of secession, on the other hand, means that the states can reject the authority of the general government entirely, without making it, as the right of nullification an agent of the states does. Finally, Wheare $(1946 / 1963,92)$ comes to the conclusion that even if the right of secession may be compatible with federal government, it is not compatible with good federal government. An exception could be made so that the right of secession could be granted in such a way the states would never exercise it, but this generally weakens the government (Wheare 1946/1963, 92). In conclusion, neither secession nor nullification is compatible with federalism.

\section{Secession right in federal states}

Secession, in the final analysis, may prove to be highly dependent on prevailing historical circumstances. In some cases secessions have been the result of revolts and wars, in others they were peaceful, sometimes called "velvet divorce" or "rupture tranquille" ("peaceful rupture"). Peaceful secessions are always achieved through established legal processes: even if they bring about a constitutional change, this is achieved constitutionally. In this case there is no "legal rupture" (Young 1994, 787) as in the case of a unilateral declaration of independence. Secession may occur for a variety of reasons, such as geographical position, social problems, economic interests, political aspirations as well as psychological matters.

Only a few "federal states" have included the recognition of the secession right in their Constitutions: the former USSR (1922, Art. 17 and Art. 72 in the revised Constitution from October 7, 1977 to 1991); the former Yugoslavia (1945-1946, 1963-1991); the Constitution of the Malaysian Federation (1957-1965); St. Kitts-Nevis (until 1983) and Ethiopia (1962-1993 and 1994 - present). Before going to the analysis of some of these experiences with secession in federal states, it has to be mentioned that there have even been some confederations and international organisations which have not included any secession right. The Articles of the American Confederation (1777 (1781 ratified) -1787) excluded the secession right and referred to a "perpetual union" in the preamble. Art. XIII reads: "the Union shall be perpetual; nor shall any alteration at any time hereafter be made in any of them; unless such alteration be agreed to in a Congress of the United States, and be afterwards confirmed by the legislatures of every State". The South Confederate States of America (1861-1865) did not include any secession in their "Constitution" (Note 11) either: "We, the people of the Confederate States, each State acting in its sovereign and independent character, in order to form a permanent federal government ...". (Note 12) There was no nullification or secession right, neither explicitly nor implicitly. The Charta of the United Nations (UN) and the Statutes of the International Health Organisation are more recent examples where the secession right is not included. These are admittedly exceptions. Most of the international treaties include the secession right. (Note 13) However, they do not, of course, do so unilaterally: e.g. Deutscher Zollverein (German Tax Union) (March 22, 1833, Art. 41), European Free Trade Agreement (Art. 42) etc. Other international organisations permit the withdrawal after a certain period of time, e.g. Art. XII, $\S 3$ of the Western European Union admits it after fifty years. Withdrawals from international organisations are quite normal and frequent, e.g. Canada and the US withdrew from the Organisation for Industrial Development of the UN. (Note 14) The International Atomic Energy Agency allows its members to withdraw only when they do not want to vote upon the revision of the statutes.

The following section presents an analysis of those federal states which have admitted the right of secession in their Constitutions.

\section{Former USSR}

Art. 70 of the 1977 Constitution of former USSR reads: "The USSR is an integral, federal, multinational state formed on the principle of socialist federalism as a result of the free self-determination of nations and the voluntary association of equal Soviet Socialist Republics". The principle of "free self-determination" was, of course, violated, since Lithuania, Estonia or Moldova were never asked whether they wanted to belong to the USSR. On the other hand, Art. 80 gave a great deal of freedom to the individual republics. They could sign international treaties and become members of 
international organisations - Ukraine, for example, was a member of the Council of Europe at the same time as a member of the USSR. This is not the case of any federal unit in a federal state. Art. 72 reads: "Each Union Republic shall retain the right freely to secede from the USSR". (Note 15) This was of course a myth (Alksnis 1991, 64). This article provided no legal mechanisms for the enforcement of the secession right. Potential unilateral secession was considered by the soviet authorities to be in violation of Art. 73 and 74 of the Constitution, which provided for the supremacy of the Soviet law and sovereignty. Secession was condemned by the Communist leaders as "fundamentally opposed to the interests of the mass of the peoples both of the center and of the border regions" (Welhengama 2000, 310). The USSR Law on Procedure for Deciding the Secession of a Union Republic of 1990 made attempts at secession impossible, stating that Republics had to get the consent of the USSR Supreme Soviet before seceding. Secession would be possible only through a $2 / 3$ majority in a referendum and after a five-year transition period. At the beginning of the 1990s, the first unilateral move for independence, also called "secession" took place (Lithuania, March 11, 1990), later Latvia, Estonia, Ukraine, Moldova etc. followed on the basis of this procedure. On December 8, 1991, the former Russian President Boris Yeltsin signed the Bela Vezha Agreement stating that: "the Soviet Union as a geopolitical reality and a subject of international law has ceased to exist". On December 26, 1991, the Supreme Soviet Court officially dissolved the USSR (cf. Friel 2004, 421). Estonia, Latvia and Lithuania justified their secession with the argument that they have never voluntarily adhered to the USSR, and that they were therefore simply taking back what had belonged to them previously, that is their independence (cf. Mälksoo 2003). When they were annexed to the USSR in 1941, many international states, e.g. US and Germany did not recognise that annexation. This can mean that these states were not being newly formed, but merely their long standing independence was finally being recognised. The end of the USSR can actually be considered as the dissolution of the whole federal state, rather than secession of the republics.

\section{The former Socialist Federal Republic of Yugoslavia}

Art. 1 of the 1974 Constitution of the former Yugoslavia recognised the right of every nation to self-determination, including the right to secession. However, there was no mechanism in the Constitution to implement such a right. When Yugoslavia disintegrated in 1991, Serbia accused Slovenia and Croatia of secession, and of thereby threatening the integrity of Yugoslavia. The latter claimed that they were not seceding as Yugoslavia had ceased to exist prior to their declaration of independence on June 25, 1991. The statements of the representatives of the UN were very ambiguous. Some of them recognised the right of self-determination; others said that the peoples of Yugoslavia had to decide about their future. However, a right of secession of the peoples of Yugoslavia was not explicitly acknowledged. Germany was the initiator followed by other European states, the EC and the US of the moves to recognise these independent states. (Note 16) This act of recognition was against the doctrine of international law that prohibits the recognition of secession when the central government opposes it.

Eritrea, as an autonomous unit, was federated with Ethiopia under the UN Declaration in 1952. From the moment of the creation of the federal state, Eritrea began to organise resistance against Ethiopia, leading to a secessionist war in 1970s.

The Ethiopian Constitution of 1994 allows that every nation, nationality, and people of Ethiopia have an unconditional right of self-determination, including the right of secession (Art. 39, 1). Not only the nine sovereign ethnic states have the right to secede; every minority tribal group in each of the nine states also has the right of secession. This is, however, a radical change in the Ethiopian constitutional tradition.

The Malaysian Constitution states that a region may be dissociated by a mere act of Parliament (Shafruddin 1987, 26). Singapore is the only region that was formally expelled from the Malaysian federal state before it seceded in 1965. Singapore, in its turn, introduced a provision in the Constitution which states that: "... no part of the sovereignty of the Republic of Singapore" can be surrendered or transferred in any way (including joining another sovereign territory, e.g. a reunion with Malaysia) unless approval is given by a two-thirds vote of the people of Singapore in a nationally-organised referendum (Singapore Constitution, Part III, Art. 6).

South Africa, while it looks like a federal state according to its system of government, has not yet adopted the label "federalism" in its Constitution. The Constitution of South Africa (1996) provides some encouragement to secession. Section 235 states: "The right of the South African people as a whole to self-determination, as manifested in the Constitution, does not preclude, within the framework of this right, recognition of the notion of the right of self-determination of any community sharing a common cultural and language heritage, within a territorial entity in the Republic or in any other way, determined by national legislation" (emphasis added). (Note 17) The phrase "or in any other way" might be used by secessionists to justify their separatist claims. Some states consider that there is a link between the situation of minorities and self-determination. They could exercise certain rights in the context of internal self-determination, but they have to maintain the national sovereignty and territorial integrity of states in which they live.

This presentation has shown that when the secession right is included in the constitution, sooner or later the federal units will profit from it. In the case of the USSR, secession happened because the republics were included in the federal 
state by force and some of them did never give full consent to the union: in short, there was no democracy. The soviet case thus involves a remedial right of secession since the territories were unjustly annexed. In the case of Eritrea, resistance to the federal state was expressed from the very beginning of its creation. In all the cases, the federal government failed to protect the basic rights and security of its citizens and the economic interests of the federal units. There are different constitutional provisions for secession, but none of them allows a unilateral right of secession, besides St. Kitts-Nevis. This Constitution provides that a referendum and a legislative approval for secession are limited only to the seceding unit, the island of Nevis. Every state that is governed democratically and respects the human rights of its citizens is entitled to have its territorial integrity respected.

The following federal states have never allowed the right of secession in their Constitutions, however, secession either happened or became a very controversial issue.

The secession of Bangladesh from Pakistan took place in 1971. In the preceding years, East Pakistan (as Bangladesh was known between 1947 and 1971) was economically exploited by West Pakistan. Between 1965 and 1970, 64 percent of the resources of the Five Year Plan were spent on West Pakistan and 36 percent on East. However, the East Pakistan was in much greater need for help, as well as being more populous. Mujibur Rahman's Awami League participated in the election of December 1970 with a platform, which demanded autonomy for East Pakistan. His party won 72.6 percent of the votes and 165 out of 167 seats in East Pakistan and also had a clear majority in the Parliament of Pakistan as a whole. However, the Pakistan military authorities did not hand over power to Rahman's Awami League. The East Pakistani citizens were systematically excluded from leading positions in the Pakistan government, bureaucracy and army, even though the region contained 56 percent of the population of Pakistan as a whole. India "invaded" West Pakistan on humanitarian grounds and, thus "liberated" Bangladesh from Pakistan. India was not supported by the UN at the beginning, and it was only when the Indians had secured militarily victory that the secession of Bangladesh was recognised (Premdas et al. 1990, 83-94).

Czechoslovakia became a federal state in 1969 and never allowed the right of secession. When the Slovaks began campaigning in earnest for their independence, the President of Czechoslovakia Vaclav Havel despite being an advocate of the unity of the federal state, declared that if they wanted independence, they could not be prevented from achieving this. The only condition demanded was that it had to be done in a civilised way. A peaceful "velvet divorce" finally took place in 1993 (Note 18).

The Swiss Constitution of 1975 allowed cantons to split into half cantons, but did not allow them to secede from the federal state. In 1978, four districts separated from the canton Bern and formed a new canton Jura. Specific changes were made to the right of secession in the 1999 Constitution. Art. 53, $\$ 3$ reads: "Modifications of the territory of a Canton are subject to the assent of the population concerned, of the Cantons concerned, and the assent of the Federal Parliament in the form of a federal decree".

In 1919, the federal unit Vorarlberg wanted to secede from Austria in order to become a canton of Switzerland. Switzerland refused to accept this request and Vorarlberg is still part of Austria (in: Doering 2002, 50). It is not always only the will of one part, the other has to agree as well.

The state of Western Australia attempted to secede from the federal state in 1933-1934. In 1934, a petition was made to the United Kingdom Parliament to pass an act for its secession from the Commonwealth of Australia, but did not succeed. A select committee of the House of Lords and the House of Commons decided that the Parliament was not authorised to deal with such a matter that is to rule on the petition of an individual Australian state. The conclusion was that there was no right of secession for any constituent state acting unilaterally. The desire for secession in Western Australia was eventually dampened by concessions from the centre resulting in the rectification of the perceived economic injustice that have given rise to the referendum to secede (Wheare 1946/1963, 91; Zarkovic Bookman 1993, 7). Western Australia's proposal to secede appears to have been a "bargaining counter" in that the states had otherwise struggled to get better financial terms from the federal government.

The Spanish Constitution (Spain functions as a federal state, but it does not have the label "federalism" in its Constitution) even prohibits a referendum on secession.

\section{Canada}

There is no secession right allowed to the Provinces in the Canadian Constitution. However, Quebec had already tried on two occasions. The result of the referendum on sovereignty in Quebec in 1980 was of 40.4 percent "yes", while in 1995 it was of 50.48 percent "no" against 49.52 percent "yes" - a mere 54,288 votes of the 4,671,008 ballots casted making the difference (Bayefsky 2000; Turp 2003, 167-206). On September 26, 1996, the federal Government of Canada submitted a request for an advisory opinion to the Supreme Court of Canada. In its August 20, 1998 Reference re Secession of Quebec, the Court gave (Note 19) an opinion on the legality of Quebec secession and a statute, the Clarity Act, which codifies the Supreme Court's decision. The federal government passed the Clarity Act in 2000. Thus, Canada has legislative guidelines for secession, but the right of secession is not substantively or procedurally 
entrenched. The Court stated that Quebec did not have any right to declare its independence unilaterally, neither according to constitutional nor to international law. The Supreme Court stated that no province has the unilateral right to secede from the rest of Canada, but secession is legal and conditional under the Canadian Constitution. The federal and provincial governments had a constitutional and mandatory duty to negotiate if Quebec should vote in favour of sovereignty (Quebec Secession Reference, §88). In doing so, they should be guided by four fundamental constitutional principles: democracy, federalism, constitutionalism and the rule of law, and protection of minority rights. The federal and provincial governments should introduce a constitutional amendment ratifying the secession of Quebec. The Court also stated that the right of secession is based on the democratic nature of Canada and could be allowed, but that there has to be a clear majority in favour of a clear question of secession, and secession could take place only if all the Provinces agree. The Court did not agree that the referendum in 1995 provided a clear question. The question asked to Quebec was not whether or not it wanted to secede. The question of whether there could be an alternative relationship between Quebec and Canada was not a clear question at all (Friel 2004, 418-419). The Clarity Act finally identifies who determines what a clear majority and a clear question should look like. The federal government in the form of the House of Commons should determine these questions. Quebec struggled for more social justice, for a better society. The independence movement of Quebec has changed Canada in significant ways. It campaigned for more social justice and for a better society, and has shown that Canada can and should be a modern and "normal" nation-state, but it also weakened the federal principle and the acceptance of asymmetrical characteristics of the Canadian political system. The independence movement of Quebec did not obtain the desired international recognition as an independent state, but Canada can profit from it and proclaim itself as the only federal state that precisely provides the democratic and constitutional conditions of a legitimate secession for its federal units.

\section{United States}

In the USA, the right of secession proved to be highly controversial. Initially, it was never clear what the Constitution actually provided for in this regard. The Civil War of secession (1861-1865) was the ultimate outcome of this ambiguity. The "federalists" ignored the difference between treaty and constitution and asked to have a secession right in the federal state as had existed in the confederation, while the "unionists" clearly differentiated between treaty and constitution and did not want to accept the secession right (Fischer 1957, 42). The secession war is called Civil War because the act of secession was not legitimate and led to a revolutionary movement. The term "secession war" comes from international law, while the term "civil war" derives from internal law. The American secessionist crisis was both international and constitutional. It was international because the question was whether a state could secede from the Union. It was constitutional because the essential question was who in a federal state had the power to interpret the dispositions of the federal pact. Livingston objects to the secession war being referred to as "Civil War", since the US was not a state, but a federal state, where each unit was a state in itself (Livingston 2003, 18).

During the first years of the federal Constitution and before the Civil War, the US was confronted with many existential problems. This includes issues related to the constitutional crisis of an internal political nature, defence and foreign affairs, the question regarding protective tariffs and how the federal government spent the funds generated by tariffs and other taxes. An issue of an absolutely different nature was slavery, which became very significant in the $1820 \mathrm{~s}$. The leaders of the Southern States felt threatened when the Congress broke the convention that new states would be admitted to the union on the basis of one slave state for one free state. When Northern politicians ignored the warnings of Calhoun and others on this issue, they provoked the secession by Southern States, whose leaders felt that their interests and the future structure of the society was in danger. For liberals, such as Birch, this secession was justified (Birch 1984, 600-601). The Supreme Court declared in 1868 that "the Constitution in all its provisions looks to be an indestructible union, composed of indestructible states" (quoted in: Wheare 1946/1963, 91). The states could have the right to secede only in the event of a constitutional amendment to that effect. Today "no serious scholar or politician argues that a right to secede exists under American constitutional law", since "such a right would undermine the Madisonian spirit of the original document" (Sunstein 1991, 634). Nonetheless, attempts at secession do still arise. The twenty-seven Northern counties of California have introduced in the state legislature in January 1992 a plan to secede from California and to form a new $51^{\text {st }}$ state of the USA. These counties did not, however, form no single administrative, cultural etc. unit. (Note 20) More recent are the secession movements in Hawaii. (Note 21)

It would have been interesting here to examine some other cases of secession, e.g. Hungary from Austria (1867), Norway from Sweden (1905) or Iceland from Denmark (1944), but these cases did not involve federal states and this is a task larger than can be accomplished in this paper. We have seen from the above that secession is present phenomenon weather or not it is provided by the constitution. The federal level and especially the seceding unit seek stability, the former for damage control and the latter for international credibility (Young 1994, 788). Some countries like Ethiopia and St. Kitts-Nevis provide a clear constitutional right to secede, as well as concrete procedural rules on secession. Other countries, like Austria, do not provide any right of secession, but have clear procedures in respect of changes to the country's territory which could be classified as involving implied right of secession. Switzerland has no constitutional right of secession, but provides specific means of the creation of new cantons. This also applies to Canada, 
but the Supreme Court gives secession guidelines and the Clarity Act constitutional principles for secession. When the right of secession is legalised in constitutions it is used as a tactic to unify regions in a stronger union for the purpose of securing political, economical and social benefits. However, it is very of then the case that once this goal is achieved, the right of secession is delegitimised, either politically or legally. If the right of secession is not explicitly stated in the constitution, there is always an opportunity to discuss, interpret or invoke moral and legal rights in order to achieve it. Such matters as geographical reconsiderations, morality, liberty and, very importantly, economic grievances have always represented a great role in secession movements. Anderson (2004: 18) even expresses the view that choosing between federalism with the possibility of secessionism, and unitarianism with a guaranteed secessionism or, worse yet, civil war hardly represents a real choice.

\section{Secession right in the $\mathrm{EU}$}

It might appear strange to talk about secession in the framework of the EU now, at a time when its enlargements are so successfully realised and the EU has such a strong magnetic effect on other countries willing to join it. However, with the introduction of Art. I-60 (Note 22) "Voluntary withdrawal from the Union" in the Treaty establishing a Constitution for Europe (Note 23), this subject has become more and more divisive and needs to be discussed. Another reason to discuss the subject of secession is the advanced level of integration in the EU, since more the integration process advances, and the closer the political and economic ties among the member states of the EU become, the more the states feel that they are transferring a large part of sovereignty to the EU, something which many fear will be impossible win back. The expansion of the areas in which the qualified majority rule applies, is also perceived as threatening to the member states. As a result of this individual member states are reluctant to engage themselves too much in the integration process, a tendency that of course has a negative impact on the effectiveness of the EU. By contrast, if a state has the right to withdraw from the Union when it wants, it will not have any problems with transferring as much sovereignty as is needed to the EU in order to contribute to the deepening of the integration. If we see the EU merely as an international organisation based on treaties, then there is no problem to include the secession right. The fact is, however, that the EU is more than a confederation and less than a federal state, it is a federal polity or a Bund, and the EC/EU Treaties have a constitutional character (Harbo 2005). In the EU, sovereignty is shared between different levels of government. Consequently there are elements of self-rule and shared-rule, which gain effectiveness through the subsidiarity principle. Community law has supremacy over national law. There are multiple demoi and double citizenship, that of the member states and that of the EU. However, the EU is not a true federal state. Member states remain the "masters of the Treaties". The second and third pillars are almost confederal. The EU has federal features as far as the rule of law is concerned, but it is much weaker regarding the representative government. The EU is essentially based on supranational law and intergovernmental politics. Even in this case, the sui generis character of the EU could be raised and a sui generis secession right allowed on this basis, but the new Treaty establishing a Constitution for Europe is a Constitutional-Treaty, a legal document of a Bund. Is the introduction of Art. I-60 simply the legalisation of a possibility which existed previously or is it something new? Is it compatible with the constitutional character of the EU and the federal idea?

The debate initiated by the introduction of Art. I-60 in the Constitutional-Treaty is not the first time that secession in the EU has been talked about. Apart from the best known case, the withdrawal of Greenland in 1985, there have in fact been a number of attempts at secession.

The French policy of the empty chair. France did not agree with the agricultural policy of the European Community (EC) discussed during a Council Meeting in 1965 and called its representatives in the EC back to Paris. Aside from is basic disagreement with the policy, the French also took this step because they were afraid of the prospect of the supranationalisation of the EC through qualified majority decision-making within the Council of Ministers, insisting on giving veto rights to every state. From July until December 1965, France did not take part in any meeting of the European Council and the Council of Ministers. On January 26, 1966, the "Luxemburg compromise" was brokered, according to which the six member states formally "agreed to disagree" (Weiler 1985, 289). This Accord gave the possibility for every state to use the veto right, when decisions of the Community contradicted vital national interests. Weiler calls this case "withdrawal from active participation", or with other words "inactive membership" (Weiler 1985, 288-230), which is a small step in the direction of secession.

The plans of withdrawal of Great Britain. In 1974, just shortly after Great Britain became member of the EC, the Labour government asked for economic reasons to revise the conditions of membership. With sixteen votes pro and seven contra they managed to organise a referendum and ask the people if they wished to stay in the EC. On June 5, 1975, the referendum took place. The question asked was: "Do you think that the United Kingdom should stay in the European Community (the Common Market)?" With a turnout of 65 percent, 67.2 percent voted to stay, while 32.8 percent were opposed (Irving 1975). The results show that there was no danger that Great Britain would withdraw, but it is important to consider such a case as a threat to integration. Another attempt was made in the statement by the national executive committee of the Labour Party on July 27, 1981, where it is said that if the Labour Party won the elections, 
Great Britain might withdraw without organising any referendum. (Note 24) The committee presented economic reasons again, i.e. the excessive financial contribution to the EC, the weakening of the British industry and the high value of the North Sea oil. The party based its arguments for withdrawal on international law. None of the member states took a position regarding the referendum, which might be interpreted in terms of an understanding that unilateral withdrawal was not excluded. An opinion poll result of 1999 shows that 39 percent of British citizens would vote in favour of exiting the EU in a new referendum. (Note 25)

Greece announcement of secession in 1981. In autumn 1981, a few months after the accession of Greece to the EC, the socialist party $(P A S O K)$ announced that it would organise a referendum to leave the $\mathrm{EC}$ if it won the then forthcoming elections. They duly won the elections, but the referendum did not take place: the President Constantine Caramanlis was in favour of the membership of Greece in the EC and Greek law prohibits the organisation of a referendum against the will of the President. (Note 26) This is again a threatening case for the integration process. If a continuous will of the member states to advance is not maintained, the Union may stagnate.

Greenland's secession in 1985. This was the real case of secession from the EC. Greenland was not a direct member of the EC, but when Denmark became member on January 1, 1973, Greenland (Note 27) was included in the EC as a part of Denmark according to Art. 227 of the EC Treaty, Art. 79 of the European Coal and Steel Community (ECSC) Treaty and Art. 198 of the European Atomic Energy Community (Euratom) Treaty. However, when Denmark voted in a referendum on October 2, 1972 to join the EC, Greenland was opposed, this mainly because of suspicion regarding the EC fisheries policy (Krämer 1983, 273-289). Greenland was a colony of Denmark until a constitutional amendment in 1953, when it became official part of Denmark. The status of Greenland within Denmark was subsequently changed. In 1978, Greenland was given an autonomous status and a system of home government was established on May 1, 1979. Greenland's desire to withdraw from the EC was based on a variety of reasons: a) the anonymity of the "far-off Brussels" administration and the "capitalistic" features of the EEC; b) complaints against Denmark because it had forced the island into the EC; c) Greenland's desire to have lower food prices than in the EC and more control over the fishery (cf. Krämer 1983, 277). A consultative referendum was organised in Greenland on February 23, 1982, where 52 percent were in favour of secession. Greenland demanded secession despite the fact that it profited from the EC in a number of respects. The EC contributed greatly to the economic development of the island through the structural funds. The products of Greenland had an unconditional free entry to the Common Market. With a decision of the Parliament of Greenland (Landstyre) from March 26, 1982 negotiations started with the EC through Denmark to give Greenland a status of Overseas Country and Territory according to Art. 131-136 of the Treaty of Rome. The European Commission and the European Parliament (EP) gave their approval to the Council of Ministers, although there was a minority within the EP that did not agree with the leniency of the procedure for withdrawal. (Note 28) This was decided upon the Council of Ministers in an Agreement on February 20, 1984, which entered into force on February 1, 1985. (Note 29) The withdrawal procedure was complex: first, the main EC institutions were involved in the process, second, all the member states gave their agreement. It also decided the status of the withdrawal party. This withdrawal is very often considered as a precedence case for other members of the EU. However, it cannot in fact form a precedent for other regions of the EU, since: a) Greenland is an overseas, non-European territory (it belongs geographically to the North American continent); b) it is a former colony affiliated to a member state, and c) a developing area (Harhoff 1983, 31). On the other hand, the case of Greenland cannot be seen as withdrawal according to international or EC/EU law, since Greenland was not a direct member of the EC. The separation of Algeria from France in 1962 cannot be seen as withdrawal either, merely as the reduction of the territory of a member (cf. Waltemathe 2000, 25). Greenland's withdrawal did not even change the voting power of Denmark in the EC institutions. The fact remains, however, that withdrawal did take place: Greenland now even no longer is an indirect member of the EU.

\section{The absence of a secession right in the EC/EU Treaties}

Even if Greenland had seceded and other attempts at secession existed, the secession right has never been explicitly or implicitly included in the EC/EU Treaties. There were a number of proposals at the beginning of the integration process to include such a right, but none was adopted. The French proposal to include a secession right in the Treaty of Rome was rejected (Toulemon 1994/1999, 26). The Protocol of Germany from 1957 has been interpreted as unilateral secession and was not introduced in the Treaty of Rome. (Note 30) The draft European Constitution of Spinelli (1984) (Toulemon 1994/1999, 61) also included an article providing a right to leave the Union under "fair conditions". Later, a European Constitutional group in London made a "Proposal for a European Constitution" in 1993, Art. XXX of which provides a clear secession right. Before the Intergovernmental Conference (IGC) met in 1996, it was proposed that the next revision of the EC Treaty should include a secession right, or that a member state should have the possibility to leave the EC according to its own constitutional provisions. (Note 31) A resolution of the EP concerning the EC Treaty in the context of the IGC in 1996 states that a clause should be included in the next Treaty according to which a state may withdraw from the Union under special conditions. (Note 32) However, the intermediary report rejected this proposal before the IGC took place. One of the reasons for this was that the advanced integration would be questioned and difficulties would appear for the next phases of integration. The other reason why the secession right has never been 
included in the Treaties could be due to what Weiler stresses: "the reluctance to talk about divorce on the wedding day" (Weiler 1985, 282). The promoters of European integration, like Jean Monnet and Robert Schuman wanted to achieve unity in Europe. They did not think too much about the worst scenario.

Nevertheless, lawyers still cannot agree whether the EC/EU Treaties allow secession. If the EU is understood to be based on international law, then according to Art. $54 \mathrm{~b}$ of the Vienna Convention on the Law of Treaties (VCLT) (May 23, 1969), a unilateral withdrawal is excluded, unless it is explicitly included in the Treaty (Note 33) as this would violate the principle of pacta sunt servanda. It could be allowed only in extreme cases, e.g. when serious violations of the Treaty are identified (Art. $60 \mathrm{VCLT}$ ). Art. 56 of the VCLT on the denunciation of or withdrawal from a treaty containing no provision regarding termination, denunciation or withdrawal states that withdrawal is possible only when: (a) it is established that the parties intended to admit the possibility of denunciation or withdrawal; or (b) a right of denunciation or withdrawal may be implied by the nature of the treaty. The EC/EU Treaties being based on an "ever closer union" clause with an unlimited duration do not imply any intention to admit withdrawal. The EC and Euratom Treaties did not take the example of the ECSC Treaty which included a limited duration. The fact that this right was not included in the Treaties suggests strongly that none of the founding parties had the intention to leave the Union. It cannot, therefore, be assumed that Art. 56 of the VCLT provides withdrawal for EU member states. It could also be argued that: "... sovereign States would not have intended to abandon permanently and irrevocably their right to withdrawal without expressly so doing" (Friel 2004, 408). If international law under the clausula rebus sic stantibus (Art. 62 VCLT) allows the end of a treaty in some exceptional cases, it does not do this as far as the EU is concerned (Ipsen 1972, 100). Art. 62 reads that a state can use the fundamental change of circumstances clause for terminating or withdrawing from the treaty only when 1: (a) the existence of those circumstances constituted an essential basis of the consent of the parties to be bound by the treaty; and (b) the effect of the change is radically to transform the extent of obligations still to be performed under the treaty. This is not the case of the EU, since its members have declared in all the revisions of the Treaties that they want to achieve further economic and political integration.

It is true that the $\mathrm{EC}$ and later the $\mathrm{EU}$ were based on international Treaties, but according to the jurisdiction of the European Court of Justice (ECJ), there is a principle prohibition of the secession right, since the ECJ takes the EC/EU Treaties as a "constitutional Charta" (Note 34) (cf. Bruha/Nowak 2004, 1-25). The EU has its own legal order, which belongs neither to international law nor to domestic law. EU law has supremacy over national law (Note 35), direct effect (Note 36) and pre-emption. The will of a member state to secede from the EU contradicts EU law, which is superior to state law: state law, accordingly is overruled. "Legally speaking therefore secession is impossible, since the cumulative effect of the lack of an express process of secession, when coupled with the doctrine of supremacy, would negate any State act to withdraw from the EU" (Friel 2004, 412-413). The doctrine of supremacy is similar to the federal jurisdiction, which is against withdrawal. Thus, a unilateral withdrawal cannot be allowed, not only according to international law, but also according to EC/EU law.

Some lawyers, however, see in particular an implicit expression or prohibition of these norms. The first is the principle of "eternity" of the European integration. The Treaty establishing the ECSC - a confederation was signed in 1951 for a limited duration of fifty years (Art. 97 ECSC until July 23, 2002) and did not include any secession right. However, Art. 240 of the Treaty of Rome (1957) (later Art. 51 EU Treaty and Art. IV-446 Constitutional-Treaty) states that the European Economic Community is: "concluded for an unlimited period", meaning that unilateral secession is illegal. The proposals of including a limited period of time in the Treaty or even a clause founding an "eternal Bund" were rejected on the basis of the view that goals of European integration were incompatible with the idea of a limited duration of the Union. The project of the European Political Community (1953), which failed, used an even stronger term. The Community had to be "indissoluble": "Il est institué par le présent traité une Communauté européenne de caractère supranational. La Communauté est fondée sur l'union des peuples et des Etats, le respect de leur personnalité, l'égalité des droits et des obligations. Elle est indissoluble". (Note 37) If this project had succeeded, then the secession right would not have had any place in it. Duration excludes secession, as has been shown above. However, the term "unlimited" does not necessarily imply that the Treaty should be permanent and that withdrawal is prohibited. It is not comparable to a labour contract, for example, from which withdrawal is possible. The same applies to economic contracts concluded for an unlimited period: "Même en l'absence de clause résolutoire ou de dédit, la faculté de rupture unilatérale existe toujours dans les contrats à durée indéterminée, à condition de respecter un préavis et sous réserve de la théorie controversée de l'abus de droit" (Feldman 2004, 506). (Note 38)

What could be conflicting with secession is the "ever closer union" clause. From the Treaty of Rome (1957) until the Constitutional-Treaty there is an article proposing "to lay the foundations of an ever closer union among the peoples of Europe". If the Treaties are explicitly intended to establish this ever closer union, then it is not obvious that the states should want to retain the right to secede from the Union.

All these provisions show that neither EC/EU law nor international law provide the unilateral right of secession. Things might change in this regard, as the Constitutional-Treaty explicitly provides such a right. This article could dramatically 
modify the character of the EU.

\section{The implications of Art. I-60 of the Constitutional-Treaty}

Article I-60 (Note 39) demands that supranationalists and federalists step back on the road to integration. According to them, if ever the EU becomes a federal state, it will need a constitutional revision, which will have to exclude the secession right. They were very reticent during the negotiations in the Convention to include such an article. One of the arguments is that if the EU is not approaching a break up, there is no need to establish a rule as to how it should be dismantled. The sovereignists, on the other hand, see the right of secession as a democratic right to allow a country to withdraw as a last resort if it wishes. A member state which entered the Union voluntarily should retain the corresponding right to exit the Union voluntarily. But can it retain this right? Can a state have the same freedom to enter and leave the Union (cf. Schönberger 2004, 103)?

This article was mainly pushed by sovereignists, who took into account such complaints as: “... l'appartenance à l'Union européenne serait une contrainte antidémocratique, presque diabolique, à laquelle les malheureux citoyens n'auraient aucun moyen d'échapper" (cf. Giscard d'Estaing 2003, 74). (Note 40) Those who support the inclusion of this article argue that the citizens are entitled to profit from the advantages of the EU, but if they believe that there are problems with the Union, the EU should not force them to stay and instead provide them with all the legal provisions to allow them to withdraw. Representatives from Denmark and Great Britain claimed that an exit clause would rob eurosceptics of the argument that the bloc was a prison from which there was no escape. This article should also help new candidates to adhere: "Art. I-59 [I-60] soll nicht Austrittswilligkeit fördern, sondern vor allem den neuen EU-Staaten ihren Entschluss zum Beitritt erleichtern, indem verdeutlicht wird, dass sie nicht in ein 'Völkergefängnis' eintreten“ (Oppermann 2003, 1242). (Note 41)

The idea of including the withdrawal right in the Constitutional-Treaty appeared for the first time in an early draft, which the Presidency of the Convention presented on October 28, 2002. (Note 42) The Presidency justified the inclusion by stating that even if such an article had not previously existed in the Treaties, it had existed de facto. If a state wished to withdraw, under previous conditions, it would be able to use the absence of the prohibition of a secession right in order to achieve its goal. When Malta was not even member of the EU, the President of the opposition party, Vella, pointed out that after the accession Malta could withdraw if it were necessary. He justified his position with the argument that: what is not legally forbidden is allowed. (Note 43) With Art. I-60 nobody will be able to prevent a state from withdrawing on the basis of the argument that this would violate Community law, as the withdrawal clause will become law. The candidate state for withdrawal would of course be obliged to respect the conditions and terms of the article.

Initially, many of the "old" member states voted against this clause. Members who were candidate members at that time insisted that this clause was "psychologically necessary" in order to be sure that the Constitutional-Treaty would be ratified. This primarily concerned the Eastern European countries Estonia, Latvia and Lithuania, who had been in the "USSR prison". The Lithuanian deputy, Liene Lepina, explained that this article was symbolic and necessary to underline the value of freedom. (Note 44) By the end of the negotiations the majority of the members of the Convention were in favour of introducing the withdrawal clause, but they also asked to introduce strict conditions, so that it does not become a "blackmail clause". The representative of the German Bundestag, Jürgen Meyer summarised this concern in this statement that: "(We should not) offer this on a silver platter to eurosceptics, they will continue to cause disruption in their national parliaments and among national public opinion whenever something difficult is proposed by Brussels". (Note 45) Danuta Hübner, the European Affairs Minister of Poland continued: "It should be made evident that the political and economic cost of withdrawal could be very high ... This would not only be just, but it would be a deterrent to use the threat of withdrawal as a political weapon in negotiations within the Union". (Note 46) An attempt at withdrawal could be fended off, if the conditions are very difficult. One might draw an analogy to family law. If a divorce procedure is very complicated, then when misunderstandings arise in a marriage, the parties will be more willing try to find compromises and continue to live together (Sunstein 1991, 650). The more difficult it is to secede, will be the efforts of the parties to stay in the union.

During the eighteenth plenary session of the Convention on April 24-25 2003, the withdrawal clause was discussed and despite all the opposing arguments it was accepted. Some revisions of the article were proposed, e.g. the representatives of the European Commission and of the French, Belgian and Dutch Governments held that withdrawal should be allowed only when the Constitutional-Treaty is revised and should be negotiated with other partners because of the advanced interlocking of the EU policies. The Spanish deputy, Josep Borrel said "yes" to divorce, but "no" to the right of the departure from the domicile. (Note 47) The eurosceptics, on the other hand, were not very satisfied, they complaining of the very strict conditions for a state to withdraw. They suggested simplifying the withdrawal procedure and to allow withdrawal to take place in a shorter period of time, that is soon after the initial announcement of intention to withdraw. (Note 48)

Art. I-60 appears under Title IX "Union membership" in the first part, not there where it would be normally located 
according to international law, that is to say, part IV "General and final dispositions". This demonstrates its significance. The first paragraph reads: "Any Member State may decide to withdraw from the Union in accordance with its own constitutional requirements". This paragraph is in conflict with Art. I-5, which assumes "sincere cooperation" and "mutual respect" between the member states and the EU, as well as with Art. I-43: "The Union and its Member States shall act jointly in a spirit of solidarity". All these are federal principles. The second paragraph explains the withdrawal procedure, according to which the EU and not the member states will sign this agreement, which acquires the status of a legal personality (Art. I-7). The third paragraph stipulates: "The Constitution shall cease to apply to the State in question from the date of entry into force of the withdrawal agreement, or, failing that, two years after the notification referred to in paragraph 2, unless the European Council, in agreement with the Member State concerned, unanimously decides to extend this period". It results from this paragraph that withdrawal can actually also take place unilaterally. However, unilateral withdrawal is neither accepted according to EC/EU law nor to international law, as has been argued above. Furthermore, withdrawal can take place without any special legal material or formal conditions. This article is thus also in conflict with Art. IV-446, which stipulates that the EU is established for an unlimited period of time. As such, if the Constitutional-Treaty including Art. I-60 is ratified, then it might imply a material change of the EC/EU legal system.

None of these paragraphs, however, clearly show, how withdrawal will take place in practice. If there is a disagreement as to whether the national decision to leave the EU was made constitutionally, then the issue should be discussed by the ECJ. Art. I-60 states very clearly that the representatives of the withdrawing state cannot take part in the discussions of the Council of Ministers and of the European Council, but it does not say whether they can take part in the discussions of the EP and ECJ. This leaves a range of questions unanswerable: How will the interlocked political and economic relations between the withdrawing state and the EU be regulated? What relationship will exist between the withdrawing state and its citizens and the EU? What about the Euro? The weighting of votes in the European Council and the Council of Ministers, the number of representatives in the EP and the Commission will also be required to be revised. The primary and secondary law of the EU will no longer be applied in the withdrawing state. Many points are thus unclear. All off this shows the limits of the withdrawal clause, which may provoke even more problems once such a case arises.

If the European integration process is looked at closely, it becomes very obvious that the goals of the EC and later EU were always very demanding. The economic, strategic, politic and defence goals represent a very deep form of integration. The Euro, common trade, fiscal and international commercial policies, the Schengen area etc. all demonstrates the ambitious and highly interconnected character of the EU, which is so much interconnected. The more the integration advances and the tighter relationships between the member states there are, the more difficult it becomes to contemplate withdrawal. The more interdependence there is, the higher the costs of secession are. The process of integration thus seems to exclude secession.

This article brings back through, in another form, the option of a "partial membership" which has been proposed so many times in the EC/EU but has never being successfully introduced. According to this idea, an "outward differentiation" ("Differenzierung nach aussen", Emmanouilidis/Giering 2003, 454, 465) would take place, which is very different from the "flexible integration" model based on a stronger cooperation of a minimum of eight states. For the EU, this article may be the beginning of a "reverse differentiation" instead of the "progressive differentiation" in the form of enforced cooperation known until now. A state might threaten the EU with secession, using the withdrawal clause in order to obtain a kind of "differentiated integration" according to its interests (Bruha/Nowak 2004, 25). Instead of compromise, this will lead to withdrawal. This article may imply, on the one hand, that the member states are still the "Masters of the Treaties", that is, that they retain their sovereignty. On the other hand, one could say that Art. I-60 weakens the member states' influence at the EU level. The fact that a member state may always withdraw could weaken its position in a negotiation process. To have another option - the withdrawal - could actually become a disadvantage for the union (Schelling 1960, 33-34).

\section{Conclusion}

The point of departure of this article was the liaison between federalism and secession. The main argument is that the right of secession is not compatible with the federal idea. All federal states are vulnerable to secessionist pressure. If the federal units are given a high level of autonomy, institutional authority and capacity, the contested right to secede comes strongly to the fore. In part one the various reasons in supporting this hypothesis were presented. In addition, the different examples were used to demonstrate the disadvantages of including such a right in the legal document of a federal polity. If a federal constitution provides a secession right, its days are numbered. One might expect that legalising secession would make the secessionists undertake a cost/benefit analysis of seceding versus staying in the union, but we have seen that this does not help. Other problems occur in cases when there is no constitutional provision for such a right. There is always a possibility to avoid secession, such as holding honest debates, looking for compromises or simply using the basic right of expression. The renunciation of secession should precede federalism and democracy. If every unit in a federal structure were to secede after every opposed decision, then no democratic 
development would be possible. If moral rights are important, how can secession be admitted in democratic states? Secession would furthermore imply that some units would loose the economic benefits of distributive justice. Finally, the EU was analysed in terms of secession. The threats of secession have always been present there, even though the EC/EU Treaties have not provided any explicit right for secession. With a possible new legal document for the EU this right might be constitutionalised. If new federal features are introduced to the EU by the Constitutional-Treaty - i.e. the motto "unity in diversity", a huge step backwards will nonetheless be made from the federal point of view with the acceptance of the secession right - that is, if we see the EU as Bund and that in a Bund, as has been shown, there is no clear possibility of secession. Federalism has never been an easy issue for the EU. With the Maastricht Treaty the EU became a federal polity, however the "F-word" was excluded. The secession right now seems to be its main challenge for the next years in achieving the aims of the fathers of European integration.

There is little to add to the argument that secession is incompatible with federalism, either in the case of federal states or of a Bund. There is no reunification after secession. Secession is irrevocable. The event of secession marks the affected society profoundly, not only in respect to the institutional changes, which take place, but also in respect of the morality of the individuals. If democracy constrained by constitutional rules is the optional system for the protection of human rights, then those who want to secede from a democratic state, or in our case from a federal polity, have in fact no moral right to do so, because they already live in a just society.

\section{References}

Alksnis, Viktor. (1991). Suffering from Self-Determination. Foreign Policy 84: 61-71.

Anderson, Lawrence M. (2004). The Institutional Basis of Secessionist Politics: Federalism and Secession in the United States. Publius: The Journal of Federalism 34,2: Spring: 1-18.

Althusius, Johannes, (1603/1965). The Politics of Johannes Althusius. An Abridged Translation of the 3rd ed. of Politica Methodice Digesta, Atque Exemplis Sacris et Profanis Illustrata. London: Eyre and Spottiswoode.

Barktus, Vivia Ona. (1999). The Dynamic of Secession. Cambridge University Press.

Bayefsky, Anne F., (2000). Self-Determination in International Law. Quebec and Lessons Learned. London: Kluwer Law International.

Beaud, Olivier. (1999). La notion de pacte fédératif. Contribution à une théorie constitutionnelle de la fédération. In Gesellschaftliche Freiheit und vertragliche Bindung in Rechtsgeschichte und Philosophie = Liberté sociale et lien contractuel dans l'histoire du droit et la philosophie. Edited by Jean-François Kervégan, and Heinz Mohnhaupt. Frankfurt am Main: Vittorio Klostermann.

Beran, Harry. (1984). A Liberal Theory of Secession. Political Studies 32/2: 21-31.

Birch, Anthony H. (1984). Another Liberal Theory of Secession. Political Studies 32/4: 596-602.

Brilmayer, Lea. (2000). Secession and Self-Determination: a Territorial Interpretation. In Self-Determination in International Law. Edited by Robert McCorquodale. Ashgate, Dartmouth, Aldershot.

Bruha, Thomas, and Carsten Nowak, (2004). Recht auf Austritt aus der Europäischen Union? Anmerkungen zu Artikel I-59 des Entwurfs eines Vertrages über eine Verfassung für Europa. Archiv des Völkerrechts 42/1: 1-25.

Buchanan, Allen. (1991). Secession. The Morality of Political Divorce from Fort Sumter to Lithuania and Quebec. Boulder, San Francisco, Oxford: Westview Press.

Buchheit, Lee C. (1978). Secession: The Legitimacy of Self-Determination. New Haven, CT: Yale University Press.

Dagtoglou, Prodromos. (1972). Recht auf Rücktritt von den römischen Verträgen. In Festschrift für Ernst Forsthoff zum 70. Geburtstag. Edited by Roman Schnur. München: C.H. Beck'sche Verlagsbuhhandlung.

Dahlitz, Julie. (Ed.). (2003). Secession and International Law. Conflict Avoidance - Regional Appraisals. The Hague: United Nations, Asser Press.

Doering, Detmar. (2002). Friedlicher Austritt. Braucht die Europäische Union ein Sezessionsrecht? http://www.cne.org/pub_pdf/Doering_Friedlicher_Austritt.pdf (accessed on December 5, 2004).

Emmanouilidis Janis A./Giering Claus. 2003. In Vielfalt geeint - Elemente der Differenzierung im Verfassungsentwurf. Integration. 26: 454-465.

Feldman, Jean-Philippe. (2004). Les Constitutions des Etats confédérés d'Amérique. Revue française de Droit constitutionnel 59: 503-531.

Fischer, Walter. (1957). Das Austrittsrecht aus Staatenverbindungen. Winterthur: Verlag P.G. Keller.

Friedrich, Carl J. (1968). Trends of Federalism in Theory and Practice. London: Pall Mall Press.

Friel, Raymond J. (2004). Providing a Constitutional Framework for Withdrawal from the EU: Article 59 of the Draft 
European Constitution. International and Comparative Law Quarterly 53: 407-428.

Giscard d'Estaing, Valéry. (2003). La Constitution pour l'Europe. Paris: Albin Michel.

Götting, Friedemann. (2000). Die Beendigung der Mitgliedschaft in der Europäischen Union. Baden-Baden: Nomos Verlagsgesellschaft.

Harbo, Florentina. (2005). Towards a European Federation? The EU in the Light of Comparative Federalism. Baden-Baden: Nomos Verlagsgesellschaft.

Hamilton, Alexander, James Madison \& John Jay. (1787-1788/1982). The Federalist Papers. New York: Bantam Classic.

Harhoff, Frederik. (1983). Greenland's Withdrawal from the European Communities. Common Market Law Reports: $13-33$

Héraud, Guy. (1993). L'Europe des Ethnies. Bruxelles: Collection Axes, Bruylant.

Horowitz, Donald L. (1985). Ethnic Groups in Conflict, University of California Press.

Ipsen, Hans Peter M. (1972). Europäisches Gemeinschaftsrecht. Tübingen: J.C.B. Mohr, Paul Siebeck.

Irving, R.E.M. (1976). The United Kingdom Referendum: June 1975. European Law Review, vol. 1: 1-12.

Jellinek, Georg. (1900/1929). Allgemeine Staatslehre. 3rd ed. Berlin: Struppe und Winkler.

Jellinek, Georg. (1882/1969). Die Lehre von den Staatenverbindungen. 2nd ed. Wien, Aalen: Hölder Verlag.

Krämer, Hans R. (1983). Greenland's European Community (EC-) Referendum, Background and Consequences. German Yearbook of International Law 25: 273-289.

Laforest, Guy. (1998). Standing in the Shoes of the Other Partners in the Canadian Union. In Beyond the Impasse toward reconciliation. Edited by Roger Gibbins and Guy Laforest. The Institute for Research on Public Policy, Canada.

Lefaucheux, Jean. (1985). Le nouveau régime de relations entre le Groenland et la Communauté Economique Européenne. Revue du Marché Commun: 81-90.

Livingston, Donald W. (1998/2002). The Secession Tradition in America. In Secession, State and Liberty. 2nd ed. Edited by David Gordon. New Brunswick and London: Transaction Publishers.

Locke, John. (1689), (1993/2002). The Second Treatise of Government. In John Locke. Two Treatises of Government. 2nd ed. Edited by Mark Goldie. London: Everyman.

Mälksoo, Lauri. (2003). Illegal Annexation and State Continuity: the Case of the Incorporation of the Baltic States by the USSR. A Study of the Tension between Normativity and Power in International Law. Leiden, Boston: Martinus Nijhoff Publishers.

Moore, Margaret. (Ed.). (1998). National Self-Determination and Secession. London: Oxford University Press.

Oppermann, Thomas. (2003). Eine Verfassung für die Europäische Union - Der Entwurf des Europäischen Konvents. Deutsches Verwaltungsblatt 1: 1234-1246.

Premdas, Ralph, S. W. R. de A. Samarasinghe \& Alan B. Andersen. (1990). Secessionist Movements in Comparative Perspective. London: Pinter Publishers.

Preuss, Ulrich K. (1997). Federalism in Pluralistic Societies: Between Secession and Centralisation. The Good Society, Committee on the Political Economy of the Good Society, vol. 7, no. 1:22-25.

Rawls, John. (1999). The Law of Peoples. Cambridge, Massachusetts: Harvard University Press.

Richard K. Cralle. (Ed.), (2003). The Papers of John C. Calhoun, Vol. XXVIII, South Carolina: University of South Carolina Press.

Schelling, Thomas C. (1960). The Strategy of Conflict. Cambridge, Massachusetts: Harvard University Press.

Schmitt, Carl. (1928/1957). Verfassungslehre. 3rd. ed. Berlin: Duncker \& Humblot.

Schönberger, Christoph. (2004). Die Europäische Union als Bund. Zugleich ein Beitrag zur Verabschiedung des Staatenbund-Bundesstaat-Schemas. Archiv des öffentlichen Rechts 129: 81-120.

Seymour, Michel, Secession as a Remedial http://www.philo.umontreal.ca/prof/documents/SecessionasaRemedialRight.pdf

Shafruddin, Bin Hashim. (1987). The Federal Factor in the Government and Politics of Peninsular Malaysia. London: Oxford University Press.

Steiger, Heinhard. (1966). Staatlichkeit und Überstaatlichkeit. Eine Untersuchung zur rechtlichen und politischen 
Stellung der Europäischen Gemeinschaften. Berlin: Duncker \& Humblot.

Sunstein, Cass R. (1991). Constitutionalism and Secession. University of Chicago Law Review, spring: 633-670.

Toulemon, Robert. (1994/1999). La construction européenne. 2nd ed. Paris: Editions de Fallois.

Turp, Daniel. (2003). Québec's Right to Secessionist Self-Determination: The Colliding Paths of Canada's Clarity Act and Québec's Fundamental Rights Act. In Secession and International Law. Conflict Avoidance - Regional Appraisals. Edited by Julie Dahlitz. The Hague: United Nations, Asser Press.

Ungerer, Werner. (1984). Der “Austritt” Grönlands aus der Europäischen Gemeinschaft. Europa-Archiv: 345-252.

Waltemathe, Arved. (2000). Austritt aus der EU. Sind die Mitgliedstaaten noch souverän? Frankfurt-am-Main: Peter Lang Verlag.

Walzer, Michael. (1986). The Reform of the International System. In Studies of War and Peace. Edited by Øyvind Østerud. Norwegian University Press.

Watts, Ronald L. (1999). Comparing Federal Systems. Ontario: Institute of Intergovernmental Relations, Queen's University.

Weiler, Joseph H.H. (1985). Alternatives to Withdrawal from an International Organisation: the Case of the European Economic Community. Israel Law Review, vol. 20, no. 2-3: 282-298.

Weiss, Friedl. (1985). Greenland's Withdrawal from the European Communities. European Law Review: 173-185.

Welhengama, Gnanapala. (2000/2001). Minorities' Claims: From Autonomy to Secession. Ashgate, Aldershot: International Law and State Practice.

Wheare, Kenneth C. (1946/1963). Federal Government, 3rd ed. London: Oxford University Press.

Widdows, Kealoha. (1982). The Unilateral Denunciation of Treaties Containing no Denunciation Clause. The British Journal of International Law 53: 83-114.

Young, Robert A. (1994). How do peaceful secessions happen? Canadian Journal of Political Science, vol. 27, no. 4: 773-792.

Zarkovic Bookman, Milica. (1993). The Economics of Secession. London: The Macmillan Press.

\section{Notes}

Note 1. See on this subject: Harbo 2005, where the author defends the theory of Bund.

Note 2. See on this subject: Dahlitz 2003, Brilmayer 1991/2000, Moore 1998, Horowitz 1985.

Note 3. Oxford Advanced Learner's Dictionary online: http://www.askoxford.com - accessed on September 17, 2004.

Note 4. "The secession of the states from the union is thus not the application of a natural right but high treason" (author's translation).

Note 5. See Seymour Secession as a Remedial Right: http://www.philo.umontreal.ca/prof/documents/SecessionasaRemedialRight.pdf

Note 6. Ibid. reference no. 5.

Note 7. See on this subject: Watts 1999, 107-108; Friedrich 1968, 21; Wheare 1946/1963, 92.

Note 8. The fundamental work on the morality of secession is that of Buchanan 1991.

Note 9. "Either the duration of the Bund, that is neither secession, nor nullification; or the independent political existence of the member states, that is - even if, only in the most extreme cases - nullification and secession. But the concept of a political entity composed of states, which is intended to last without abandoning its legal basis appears to be something contradictory to the highest degree" (author's translation).

Note 10. Except in the "personalist federation". Guy Héraud in his work "L'Europe des Ethnies" ("Europe of ethnos") points out that if the secession right is not accepted in a federal state, one has to create it, since it is not democratic for a state not to be able to go out from the union: "C'est pourquoi il convient de 'construire' le droit d'autodétermination" (Héraud 1993, 190-191). ("That is why it is necessary to 'construct' the self-determination right" (author's translation)).

Note 11. All the attempts to include it were rejected: e.g. the projects of William Waters Boyce from South Caroline and Hill from Georgia among the others were rejected by the Convention. Fifteen states' Constitutions formed between 1864 and 1875 prohibit the secession right, eleven out of them forbid the nullification right (in: Feldman 2004, 519).

Note 12. See the "Articles of Confederation" and the "Constitution of the Confederate States" online at the Avalon Project at Yale Law School - http://www.yale.edu/lawweb/avalon/avalon.htm - accessed on February 12, 2005. 
Note 13. In Widdows' calculations, there are about 4/5 of them (Widdows 1982, 98).

Note 14. Süddeutsche Zeitung, December 5, 1995, 1.

Note 15. Constitution of the Union of Soviet Socialist Republics, Novosti Press Agency Publishing House, Moscow, 1977, p. 56.

Note 16. The Declaration on the "Guidelines on the recognition of new States in Eastern Europe and in the Soviet Union", 16 December 1991, published in The Hague and Brussels on December 17, 1991, EC Bulletin 12-1991.

Note 17. Constitution of the Republic of South Africa - http://www.polity.org.za/html/govdocs /constitution/ saconst14.html? Rebookmark =1 - accessed on April 15, 2005.

Note 18. In: Frankfurter Allgemeine Zeitung, July 7, 1992.

Note 19. Reference re Secession of Quebec from Canada (1998) 161 DLR $\left(4^{\text {th }}\right) 385$.

Note 20. The New York Times, November 30, 1991.

Note 21. www.freehawaii.org.

Note 22. http://europa.eu.int/eur-lex/lex - Treaty establishing a Constitution for Europe, Official Journal, C 310, vol. 47, December 16, 2004. The Intergovernmental Conference (IGC), which discussed the Constitutional-Treaty and came to an agreement on the reform of the EU institutions that was reached at the European Council in Brussels on June 23, 2007, brought no change as far as Art. I-60 is concerned. The next IGC has the task of drawing up the "Reform Treaty" by the end of 2007, which, if ratified, could enter into force in June 2009.

Note 23. Henceforth: Constitutional-Treaty.

Note 24. "European Community: We'll Love You and Leave You" in: The Economist, July 25, 1981, 55.

Note 25. Frankfurter Allgemeine Zeitung, June 8, 1999, 7.

Note 26. See: "Greece and Europe. Would the Socialists Pull out?" in: The Economist, August 15, 1981, 48-50, and Waltemathe 2000, 24.

Note 27. The population of Greenland is of 55.000 of which less than 8.000 are Danes, the remainder being Inuit (Friel 2004, 409).

Note 28. EP Doc 1-264/83, 17 in: Friel 2004, 410.

Note 29. See on this subject: Dix-huitième Rapport général sur l'activité des Communautés européennes, 1984; Supplement 1/83 to the Bulletin of the European Communities Commission Opinion on the Status of Greenland; Waltemathe 2000, 26-28; Götting 2000, 119-121; Lefaucheux 1985, 81-90; Weiss 1985, 173-185; Ungerer 1984, 345-352; Harhoff 1983, 13-33; Krämer 1982, 273-289.

Note 30. The Protocol reads: "Die Bundesregierung geht von der Möglichkeit aus, dass im Falle der Wiedervereinigung Deutschlands eine Überprüfung der Verträge über den Gemeinsamen Markt und Euratom stattfindet" (cf. Dagtoglou 1972, 90-91). ("The Federal Government assumes the possibility to re-examine the Common Market and Euroatom Treaties if the German reunification happens" (author's translation)).

Note 31. Jacques Delors in: European Report, March 1, 1995, 2.

Note 32. Resolution, May 17, 1995, no. 17.

Note 33. "The termination of a treaty or the withdrawal of a party may take place: .... (b) at any time by consent of all the parties after consultation with the other contracting states".

Note 34. ECJ, 1/91, December 14, 1991, Rec. I-6079.

Note 35. Costa v ENEL Case 6/64, ECR 585.

Note 36. Van Gend en Loos Case 26/62.

Note 37. "The present Treaty creates a European Community of a supranational character. The Community is founded on basis of the union of the peoples and States, the respect of their personality, the equality of laws and obligations. It is indissoluble" (author's translation).

Note 38. "Even if a resolute or recall clause does not exist, the possibility of unilateral withdrawal always exists in the contracts of undetermined duration under the condition to respect a notice of dismissal presented in advance and according to the contradictory theory on the abuse of law" (author's translation)).

Note 39. See the full text of the Art. I-60 (five paragraphs) on: http://europa.eu.int/eur-lex/lex - Treaty establishing a Constitution for Europe, Official Journal, C 310, vol. 47, December 16, 2004.

Note 40 . “... the belonging to the EU would be an anti-democratic constraint, almost diabolic, from which the 
unfortunate citizens would not have any means to escape" (author's translation).

Note 41. "Art. I-59 (I-60) shall not encourage withdrawal but above all facilitate the new member states' decision to entry and make it clear that they are not entering a 'people's prison"” (author's translation).

Note 42. http://register.consilium.eu.int.

Note 43. Der Spiegel, 1999, no. 44, 198, 200.

Note 44. "La Convention sur l'avenir de l'Europe débat d'une 'clause de sortie” in: Le Monde, April 25, 2003.

Note 45. "EU Convention Backs Exit Clause with Conditions" in: The New York Times on the web, April 25, 2003.

Note 46. "EU Convention Backs Exit Clause with Conditions" in: The New York Times on the web, April 25, 2003.

Note 47. "La Convention sur l'avenir de l'Europe débat d'une 'clause de sortie" in: Le Monde, April 25, 2003.

Note 48. The representative of the German Bundestag in the Convention, Jürgen Meyer said: "Austritt aus der EU muss durch einseitige Erklärung eines Mitgliedes möglich sein" ("The withdrawal from the Union has to be possible through an unilateral declaration of a Member State" (author's translation)) - www.elearning-politik.de/europa/2002/experte. 